\section{SOI: $1.1 /$ TAS DOI: $10.15863 / \mathrm{TAS}$ International Scientific Journal Theoretical \& Applied Science}

p-ISSN: 2308-4944 (print) e-ISSN: 2409-0085 (online)

Year: 2017 Issue: 12 Volume: 56

Published: $10.12 .2017 \quad \underline{\text { http://T-Science.org }}$
Denis Chemezov

M.Sc.Eng., Corresponding Member of International Academy of Theoretical and Applied Sciences, Lecturer of Vladimir Industrial College, Russian Federation chemezov-da@yandex.ru

SECTION 25. Technologies of materials for the light and textile industry.

\title{
REQUIREMENTS FOR MANUFACTURING OF A SPEEDOMETER SCALE OF A CAR
}

Abstract: Method of printing of a speedometer scale of a car on the automatic lines "SAKURAI" and "THIEME" is presented in the article. Printing on the automatic lines allows with high accuracy to manufacture scales using high-quality paints, solvents and a polycarbonate film of the company "BAYER".

Key words: a scale, paint, printing.

Language: English

Citation: Chemezov D (2017) REQUIREMENTS FOR MANUFACTURING OF A SPEEDOMETER SCALE OF A CAR. ISJ Theoretical \& Applied Science, 12 (56): 1-4.

Soi: http://s-o-i.org/1.1/TAS-12-56-1 Doi: crossef https://dx.doi.org/10.15863/TAS.2017.12.56.1

\section{Introduction}

A mass paint production is economically advantageously in manufacturing of significant number of parts. In the composition of a paint shop (or a shop of paint coatings) are included production areas, where there are performed processes of surface preparation, priming, primary and final painting, a technological group, production and dispatch bureau, a shop laboratory, departments for preparation and distribution of paints, warehouses for storage of paint materials and a repair shop, planning and economic bureau.

The functions of the department and laboratory of paint coatings are included verification of incoming on a plant varnishes, paints, enamels and auxiliary materials, replacement if it is necessary some materials by others, development and implementation of the paint materials and new technological processes, control after painting processes and participation in designing or reconstruction of painting areas and etc. Directly, painting departments and areas serve the shop laboratories, in whose the function it is usually included systematic control and verification of production. With any method of applying coating it is verified purity of source working paint compositions (absence of any pollutions and impurities), their viscosity and the correctness configuration of products on suspensions of a conveyor. When painting by jet spraying, except for viscosity, it is verified temperature and degree of acidity of the working compositions, concentration of solvent vapors in a steam tunnel, spraying time and exposure time in vapors. When painting by electrodeposition it is verified dry residue, temperature and degree of acidity of the working compositions, presence of organic solvents, voltage, amperage and etc. In the department for preparation of paints, materials diluted to necessary viscosity for applying them on a surface one way or another method. The warehouses for storage of the paint materials are located in separate heated rooms which must be equipped with ventilation devices and fireextinguishing means. Air temperature in these warehouses must be from 17 to $25^{\circ} \mathrm{C}$ which allows to preserve good quality of the materials.

Let us consider printing method and requirements for manufacturing of a speedometer scale for cars "KamAZ" [1].

\section{Materials and methods}

The scale 87.3802.201 installs on the speedometer 87.3802. The speedometer is designed for inform of a driver about a vehicle speed, distance traveled (total and daily kilometrage), display and adjustment of current time, an alarm about exceeding of speed limit, display of a ratio of a showing device of the speedometer (number of pulses per kilometer) after entering of the access code, measuring of number of pulses coming from a speed sensor and is contributed to increasing of road safety and economical operation of the vehicle [2]. Speedometer is used in the cars "KamAZ", "MAZ", "UralAZ" and 


\begin{tabular}{l|lr|ll|ll} 
& ISRA (India) & $=\mathbf{1 . 3 4 4}$ & SIS (USA) & $=\mathbf{0 . 9 1 2}$ & ICV (Poland) & $=\mathbf{6 . 6 3 0}$ \\
Impact Factor: & ISI (Dubai, UAE) $=\mathbf{0 . 8 2 9}$ & PUHЦ (Russia) $=\mathbf{0 . 2 0 7}$ & PIF (India) & $=\mathbf{1 . 9 4 0}$ \\
& GIF (Australia) & $\mathbf{0 . 5 6 4}$ & ESJI (KZ) & $=4.102$ & IBI (India) & $=\mathbf{4 . 2 6 0}$ \\
& JIF & $=\mathbf{1 . 5 0 0}$ & SJIF (Morocco) & $=\mathbf{2 . 0 3 1}$ & & \\
\hline
\end{tabular}

"KrAZ". Drawing of the scale 87.3802.201 is presented in Fig. 1.

Mass of the scale is $2.8 \mathrm{~g}$. Material is the polycarbonate film, optical, based on biphenol A "MAKROFOL DE 6-2 0.375 mm" (company
"BAYER", Germany) [3]. The film has high heat resistance, excellent dimensional stability, easy exposed by machining: cutting, punching, stamping that identifies it for use in electronics and instrument engineering.

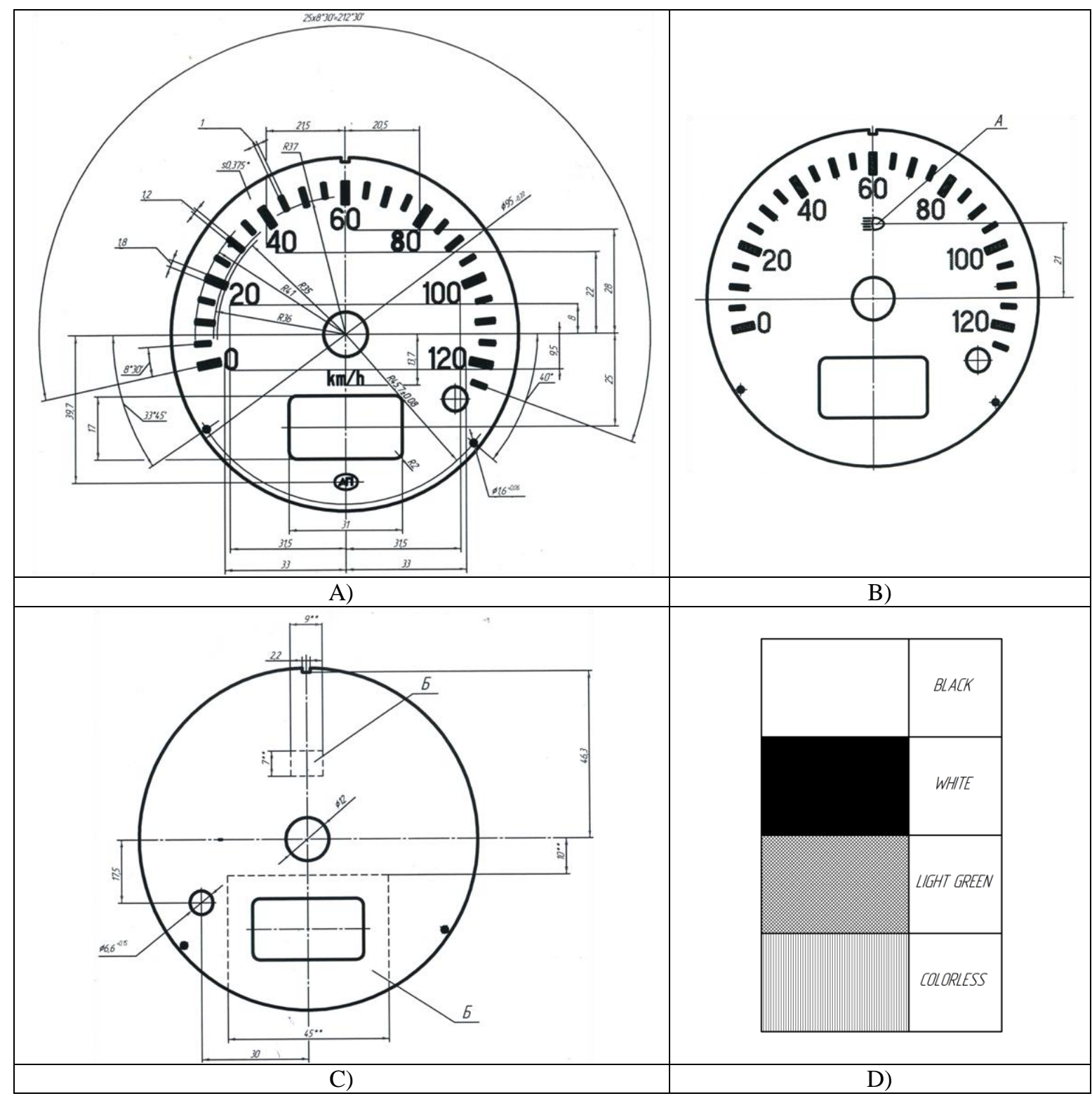

Figure 1 - Drawing of the scale 87.3802.201: A - operating mode "day", B - operating mode "night", C rear view, $\mathrm{D}$ - reference designation of coating color.

The technical requirements for manufacturing of the scale:

1. *The size for references.

2. **Unspecified limit deviations of dimensions $\pm 0.5 \mathrm{~mm}$ to provide by a tool.

3. Limit deviations of dimensions of letters, marks and numerals $\pm 0.05 \mathrm{~mm}$ to provide by the tool.
4. Unspecified limit deviations of dimensions at a location of the marks, numerals and inscriptions $\pm 0.1 \mathrm{~mm}$ to provide by the tool.

5. General tolerances according to GOST 30893.1-2002 [4]: H12, h12, \pm IT12/2.

6. General tolerances of angular dimensions according to GOST 30893.1-2002- $\mathrm{m}$.

7. Trade mark N2.5 3802226 DT. 
8. Graphical construction of the symbol A to perform in accordance with OST 37.001.012-85, coefficient is 0.087 .

9. Numerals of the marks of the speedometer to perform by basic uppercase font 6 GOST 2930-62 [5], the inscription "km/h" - letters - lowercase font 4 GOST 2930-62, the mathematical sign 4 GOST 2930-62.

10. The front surface of the scale is matte.

11. Coating of surfaces of the speedometer scale to see in Fig. 1. Coating class is IV. The group of operating conditions is $\mathrm{T} 2$.

12. White transparent paint (retouch) applies:

a) in one layer under the numbers 40,80 , as well as under the marks, appropriate 25, 30, 35, 40, $80,85,90,95,125 \mathrm{~km} / \mathrm{h}$;

b) in three layers under the numbers $0,20,100$, 120 , as well as under the marks, appropriate $0,5,10$, $15,20,100,105,110,115,120 \mathrm{~km} / \mathrm{h}$. "night".

13. Work of the scale of dual mode: "day" and

14. Medium brightness of irradiance according to OST 37.003.061-84 (allowed according to a control sample).

15. Glue is applied to the reverse surface of the scale except in areas 5 and also places under the inscriptions, marks at a distance of $1 . .2 \mathrm{~mm}$ from a corresponding contour. Glue is colorless with absorption coefficient not more than $10 \%$ and temperature range of operation from -60 to $+100{ }^{\circ} \mathrm{C}$.

16. For manufacturing of masks of the scale to use a file of this drawing.

17. Appearance by the control sample.
18. Alternate material: the polycarbonate film, optical "LEXAN 8B 35E 0.375 mm" (Netherlands).

Printing of the scale is performed from both sides (transparent polished/finely matted).

The technological process of manufacturing of the scale 87.3802.201:

1. Stencil printing of the scale on the automatic line "SAKURAI" (Japan) or "THIEME" (Germany) [6]. The size of the film is $0.375 \times 320 \times 470 \mathrm{~mm}$ or $0.328 \times 450 \times 470 \mathrm{~mm}$. Weight of the one sheet is $65 \mathrm{~g}$.

Time standard: 559 minutes on 1000 parts;

2. Punching of basic holes on a punch press.

Time standard: 192 minutes on 1000 parts;

3. Glue application (for further fixation on a lightguide).

Time standard: 480 minutes on 1000 parts;

4. Cutting of sheets to the necessary size for subsequent die-cutting of the scale.

Time standard: 94 minutes on 1000 parts;

5. Die-cutting of the scale on the hydraulic press of the company "SCHOEN" (Germany). Output is 4 pieces in one stroke of the press. For diecutting it is used a cutting die, a control template and guide retainers.

Time standard: 313 minutes on 1000 parts;

6. Control of appearance and on "gap".

Time standard: 155 minutes on 1000 parts;

7. Counting and packaging of the product.

Time standard: 107 minutes on 1000 parts.

Information about composition of paints applied to the scale and printing modes is presented in the tables 1 and 2 .

\section{Colors and composition of paints.}

Table 1

\begin{tabular}{|c|c|c|}
\hline № & Color & Composition \\
\hline 1 & Light green "illumination", No. 5529 & SR064 (green, 1 g) \\
\hline 2 & Black "retouch", No. 5533 & SR073 (black) \\
\hline 3 & White "retouch", No. 5542, one layer & SR070 (white) \\
\hline 4 & White "retouch", No. 5543, two layers & SR070 (white) \\
\hline 5 & Dark varnish, No. 5530 & SR070 (white) \\
\hline 6 & White "substrate", No. 5528 & SR073 (black) \\
\hline 7 & Black "finish", No. 5540, two layers & SR35998910 \\
\hline 8 & Matte varnish, No. 5534, sieve 120 & SR35998910 (70\%) + SR46698910 (30\%) \\
\hline 9 & Matte varnish, No. 5534
\end{tabular}

Table 2

Printing modes of the scale.

\begin{tabular}{|c|c|c|c|c|}
\hline № & Flow rate, $\mathrm{mm} / \mathrm{s}$ & Squeegee rate, $\mathrm{mm} / \mathrm{s}$ & Capture rate, $\mathrm{mm} / \mathrm{s}$ & Productivity, imprint/h \\
\hline 1 & $250-300$ & 250 & \multirow{5}{*}{$250-300$} & $652-684$ \\
\hline 2 & 300 & \multirow{4}{*}{$250-300$} & & \multirow{4}{*}{$624-684$} \\
\hline 3 & \multirow{3}{*}{$200-300$} & & & \\
\hline 4 & & & & \\
\hline 5 & & & & \\
\hline
\end{tabular}




\begin{tabular}{l|lr|ll|ll} 
& ISRA (India) & $=\mathbf{1 . 3 4 4}$ & SIS (USA) & $=\mathbf{0 . 9 1 2}$ & ICV (Poland) & $=\mathbf{6 . 6 3 0}$ \\
Impact Factor: & ISI (Dubai, UAE) $=\mathbf{0 . 8 2 9}$ & PUHЦ (Russia) $=\mathbf{0 . 2 0 7}$ & PIF (India) & $=\mathbf{1 . 9 4 0}$ \\
& GIF (Australia) & $\mathbf{0 . 5 6 4}$ & ESJI (KZ) & $=4.102$ & IBI (India) & $=\mathbf{4 . 2 6 0}$ \\
& JIF & $=\mathbf{1 . 5 0 0}$ & SJIF (Morocco) & $=\mathbf{2 . 0 3 1}$ & & \\
\hline
\end{tabular}

\begin{tabular}{|c|c|c|c|}
\hline$\frac{6}{7}$ & $250-300$ & 300 & \\
\hline 8 & \multirow{2}{*}{$300-400$} & & \multirow{2}{*}{ 200-300 } \\
\hline 9 & & & \\
\hline
\end{tabular}

Note to the tables.

No. $1 . . .4$ - printing with the matte reverse side, wiping of the stencil through 100-120 sheets.

No. 5...9- printing with the front (glossy) side, wiping of the stencil through 50-80 sheets.

For stencil printing there are used paints from the company "MARABU" (Germany) [7] and glue No. 5544.

For the module of stencil printing "MF-80" of the automatic line "SAKURAI" to set the squeegee pressure from 3 to $4 \mathrm{~atm}$. On the remote control to set: rate of the filler squeegee is 5 units, rate of the printing squeegee is 3 units [8].

During operation it is necessary continuously to control quality of printing and on "gap" before and after drying of printed on the sheet of images. Drying temperature must be $100{ }^{\circ} \mathrm{C}$. On the line of stencil printing temperature in the curing module must be $90 \pm 5^{\circ} \mathrm{C}$, temperature in the cooling module must be $15 \pm 5^{\circ} \mathrm{C}$. The parameters within specified limits are maintained automatically.

To avoid of sticking not to accumulate large number of the sheet on a palletizer (to remove and put small stacks by 40-50 sheets).

\section{Conclusion}

The technological process of manufacturing of the speedometer scale of the car in production conditions includes the mechanical, paint and control operations. According to the printing modes for the same operation it was determined processing productivity of the speedometer scale. A sequence of applying of different colors paints on surfaces of the speedometer scale was given.

\section{References:}

1. (2017) KAMAZ PTC. Available: https://kamaz.ru/en/ (Accessed: 04.12.2017).

2. (2017) Speedometer. Available: https://en.wikipedia.org/wiki/Speedometer

(Accessed: 04.12.2017).

3. (2017) Covestro Makrofol® DE 6-2 Polycarbonate. Available: http://www.matweb.com/search/datasheettext.aspx? matguid=1e200096ac724879bbed323e1f65be1a (Accessed: 04.12.2017).

4. GOST 30893.1-2002. Basic norms of interchangeability. General tolerances. Limit deviations for linear and angular dimensions without tolerance indications.

5. GOST 2930-62. Measuring instruments. Characters and signs.
6. Chemezov D, Kiseleva E (2016) A stencil manufacture in the conditions of JSC Zavod «Avtopribor». ISJ Theoretical \& Applied Science, 12 (44): 79-83. Soi: http://s-o-i.org/1.1/TAS-12-44-16 Doi: http://dx.doi.org/10.15863/TAS.2016.12.44.16

7 . (2017) MARABU. Available: http://www.marabu.com/creative/produkt/kategorien/ (Accessed: 04.12.2017).

8. Chemezov D (2017) The technological process of the manufacturing a film scale of the instrument panel of vehicle on the automated line SAKURAI. ISJ Theoretical \& Applied Science, 03 (47): 46-50. Soi: http://s-o-i.org/1.1/TAS-03-47-10 Doi: https://dx.doi.org/10.15863/TAS.2017.03.47.10 